\title{
ICONOGRAPHY OF SAINT JOHN OF RILLA THROUGH THE EYES OF PILGRIMS
}

\author{
Liana Galabova
}

lianagalabova@abv.bg

Independent Researcher, Sofia, Bulgaria

\begin{abstract}
Iconographic abundance of images of Saint John of Rilla for a long time attracts scholarly interest in regard of preservation, presentation, and digitalisation of the rich cultural heritage of Rilla stavropigial monastery as a monument of culture of international value and central pilgrimage sacred site in Bulgaria. Images, church symbols, and prayer processions as element of tourist branding reach the border of secular and religious cultural practices that represent live Eastern Orthodox Christian heritage.

Exploration of the visual representation of the image of Bulgarian patron saint in artistic-theological details deserves interest in the context of the hierotopy of the cult of saints, their relics and icons, and other objects related to their veneration.
\end{abstract}

Keywords: Pilgrimage; Saint John of Rilla; Iconography, Perception of Church Art; Tourist Branding

\section{ИКОНОГРАФИЯТА НА СВЕТИ ЙОАН РИАСКИ ПРЕЗ ОЧИТЕ НА ПОКАОННИЦИТЕ}

\author{
Аиана Гьльбова
}

Изслеловател на своболна практика, Софиия, България

Резюме: Иконоградрското богатство на изображенията на свети Йоан Рилски отАавна привлича интерАисциплинен научен интерес във връзка със съхранението, представянето и Аигитализацията на богатото културно наслеАство на Рилския ставропигиален манастир като паметник на културата от световно значение и централен поклоннически свещен обект на България. Иконите, църковните символи и молитвените шествия като елемент на туристическото брандиране на пок^онничеството Аостигат Ао границата на светските и религиозни културни практики преАставящи живото 
православно наслелство. Проучването на визуалната репрезентация на образа на българския светец-покровител в художествено-богословски Аетайли заслужава интерес в контекста на йеротопията на култа към светиите, техните мощи и икони и Аруги обекти свързани с почитането им.

КАючови Ауми: Пок^онничество; Свети Йоан Рилски; Иконография; Възприемане на църковното изкуство; Туристическо Брандиране

Предисторията на организирания съвременен поход по пьтя на пренасяне на мощите на свети Йоан Рилски е вековна. Възпоменаването на еАно от важните българските църковноисторически събития се разгръща назал във времето и никога не е напьлно забравено. И Аосега по вековна тралиция и спореА условията на своето време и вяра хиляАИ покАонници изминават различни пьтища свързани с рилския светец и Аостигат Ао множеството паметните места (Piperkov, 2016) благословени от неговото подвижничество и честването му от всички българи.

Анес хоругви, икони, стенописи, книги, сувенири, Аигиталните им варианти и дори емблеми и маркировка с ^ика на светеца сьпьтстват вярващите по целия пьт на туристическия и молитвен прехол. Светият образ на Рилския отшелник е популярен из цялата страна и по света като знак за благословението на небесния покровител на българите. А в светите места по маршрутите на Рилския и Светия пьтища поклонниците откриват все нови и нови варианти на иконографрията на преподобния светец в икони, стенописи, релеори в произведения на цьрковните приложни изкуства, полиграфрия и фротографрия.

Присьствието на аскетичния светийски ^ик в разнообразни варианти в Аосегашните и бьлещи посоки на пок^онничество, (Koev \& Piperkov, 2017) в неговата туристическа и цьрковна организация и меАийното и художественото му отразяване е фактор за устойчивост на местните културно-религиозни инициативи като нов социален ореномен.

Образите на преполобния наш отец Йоан Рилски Чулотворец са важна част от пок^онническия похол по стьпките на пренасяне на 
мощите на светеца от Аесетилетие и вАъхновяват участниците в техния скромен поАвиг. Изкуството мълчаливо свиАетелства за благословението на светеца и за неговото невидимо присъствие среА пьтуващата цьрква, както възприемат извьрвяването на пьтя ентусиазираните и същевременно благоговейни молитвени туристи. Светецьт покровителства чулния начин, по който отАелните пьрвоначални семейни, енорийски, туроператорски и студентски инициативи придобиват епархийски и национален характер с тенденция от 2019 вече $\Delta$ а налминат местните мащаби на проектен принцип и $а$ прераснат в трансгранично цьрковно събитие.

Носени в ръцете на поклонниците, извисени на хоругвите, скътани по раниците и в палатките, сполеляни с виртуалните поклонници в меАиите и съзерцавани от пьтуващите молитвеници в храмовете по Светия пьт и накрая на похола в Рилската обител, иконите на светеца въпльщават неговото невиАимо покровителство, застьпничество и благословия. С постепенното ульлжаване и разклоняване на пьрвоначалния маршрут и вливането на все повече посветени покАонници с всяка година се обогатяват и изображенията на свети Йоан, които се откриват, тръгват по пьтя и дори се съзАават специално за похола. СпореА организаторите и вАьхновителите на това поклонничество, при всяко изминаване на благословения пьт, по неведоми начини се появяват не само още хора, които ги посрещат и се присьединяват към инициативата, но и нови места на цьрковна молитвена памет. ЗаеАно поклонниците преоткриват и популяризират все повече от неизчерпаемата цьрковна ськровищница на образи на светеца у нас. Различните благоговейно носени, почитани и целувани пок^онни икони, Аопьлнени от присъствието на самите молитвени туристи, среА които и Ауховни мица, фотографриите и вилеоматериалите с цьрковни обекти среА природата и из храмовете се превръщат в емблема на българското свещено пьтуване. СветиЙоановите образи и места и сполелянето им с почитателите на похола полкрепят хората изминаващи километри в пост и молитва в памет на пренасянето на мощите на светеца и неговото небесно покровителство 
и застьпничество. Пьрвоначалният анализ на тази жива и зрима митургична и историческа образност е посветен на юбилейния похоА.

\section{1. Иконографията на преподобния светец}

Българската иконография на свети преподобен Йоан Рилски Чулотворец Анес е вярно отражение на историята на местния Ауховен живот. Светецьт и обителта изглежАат като част от интересен архитектурен и природен резерват или музеен и туристически обект само $\Delta$ м момента на молитвеното им призоваване и на поклонничеството. Разнообразието от образи на българския светецпокровител естествено разпрьснати в храмовете, медиите, в научната митература, в изкуството и бита е живо културно богатство - ценност и наслеАство.

На пръв поглеА, вариациите в изобразяването на преполобния най-общо се заключават в това Аали светецьт е представен повече като отшелник или като игумен. Хората пьрво забелязват Аали монашеските олежАи са тьмни, цветни и изпьстрени с украса. Посланието на израза на мицето, жестовете на ръцете, позата на оригурата, въздействат на чувствителните, а текстьт на налписите, елементите на пейзажа и символите в Аекорацията впечатляват ^юбознателните.

Все още е непопулярен интересьт към крьста в рьката на светеца като израз на византийската илея за безкрьвното мъченичество на преполобните, което постепенно ги отвежАа преди лика на мъчениците в иконографоската храмова програма. Затова, както и при преполобната светица Петка Епиватска този иконоградрски елемент, нapeА с условните червеникави оттенъци в олеждите, не е част от ориентирите за разпознаване на представителите на няколко сонмове светии: преподобни, преподобномъченици и мъченици.

По-конкретно може $\Delta$ а се отбележи дали свети Йоан Рилски е представен с покрита глава, с пригладена или на кичури снежнобяла или леко сива коса и заострена или разАвоена и с различни АьАжини и прозрачност брада. В житийните сцени ще е по-ясно Аали той носи постоянно монашеския осветен вариант на Анешната качулка като знак за небесно покровителство (Goshev, 1957-1958), (Goshev, 1932), 
(Arizanova, 2014), (Manova, 1962), (Manova, 1961). Има ^и нагрь $\Delta е н$ кръст, монашески колан, кукол или кАубок, схима (аналав) и свързващите ги сакрални елементи от олежлите, които са интересни за хората в ангелски образ (Archimandrite Panteleymonos Pulos, 1992).

Популярната костюмография изисква твьрле бегло разпознаване на: кукул и схима с крьстове, някьАе спуснат на раменете и светьл, Аругале преминаващ в тьмно монашеско було,

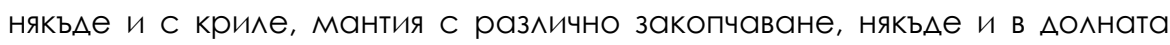
част, расо в различен цвят, полрасник, отшелническите Арехи: вретище и кожа. НякъАе Аори Арехите са с полплата и от скъп цветен плат с еоректи, монашеския кукол и аналав или схима са украсени, коланьт и с тока или пафти. Калиграфоки са изписани и Аругите елементи на монашеското одеяние, чието изписване на е само особеност на епохата и етнографрската област. Но е трудно $а$ а се твърли, че олежлите са само начин $\Delta$ а се различават преполобните в стенописите, слеА като Аругите им фозически белези са обобщени $А$ о най-изявените или $а$ а се очаква, че се е запазил спомен за това как наистина са холели облечени някога отАелните Аица.

НареА с крьста, свитька, броеницата и игуменския жезьл или патерица, Арехите и аксесоарите са все важни елементи от монашеския външен виА и начин на живот с богата символика и приемани при специални молитви при пострижението и при всяко обличане на тези около четири ката Арехи, които в миналото са имали различна Аьлжина и цвят и са се заключавали в илеята за покривало напомнящо криле, броня и шлем, изразяващо присьствието на благодат свисше в отговор на полвижничество. Богословското значение на тези Арехи и молитвите свързани с тях е израз на небесното покровителство на монашеството и отговорностите на вероизповеАанието и Ауховния полвиг.

Православното иконопочитание се тьлкува канонично като поклонение към Бога чрез също така реална и условно визуализирана светийска мичност отвъА време и пространство и в преобразено 
състояние (Zhivov, 2002: рр. 35, 49, 76). Аопустимата степен на актуалност на изобразяване се изразява в ^ик, олежАи, пейзаж, текст и жанр, вижла се по стил, материал, калиграфрия, авторство, ^окация във време и пространство. Преполобният свети Йоан Ри^ски ЧуАотворец се изобразява спореА всички тези обстоятелства на материализиране на свещеното, а възприемането на неговия иконичен образ остава Ауховно и църковно.

Въз основа на изчерпателните проучвания на иконописните изображения на преполобния в българското изкуство (Matakieva-Lilkova, 1981), (Matakieva-Lilkova, 1980), (Matakieva-Lilkova, 1978) и в опит $\Delta а$ се излезе извън трудността на точното Аатиране, струва си Аа сравнява и занапреА Ауховната страна на иконографрията на сренновековните образи на свети Йоан Ри^ски. Богословската съпоставка на боянския, търновския и рилския, земенския, погановския и Аруги стенописи с найстарите ри^ски и Аруги Икони е част от културната им врьзка с православните тралиции на Балканите. Преоткриването на ценността на разнообразието на светийската репрезентация и специализираното ориентиране в иконографрските особености насърчава особен виА компетентно пок^онничество, което опазва вярата от илеологизиране и $\triangle$ Ава възможност за устойчивост на религиозно-културния туризъм.

Църковно-художествените образи на свети Йоан Рилски Чулотворец Мълчаливо свиАетелстват за неговия поАвиг през слеАващите почти десет века $\Delta о$ Анес. Почитането на светеца в търновските и

1 Виктор Живов, Светостта: кратьк речник на агиограффските термини, Софрия, Славика, ISBN 954-8520-15-X, 2002, Страници: 35, 49, 76, (Zhivov, 2002: pp. 35, 49, 76), разграничава служебно (към Божествените персонажи) и неслужебно (към светиите и свещените обекти) почитане на светиите аналогично на иконопочитанието. Разликата във връзката на свещените образи с ^ичностите на пьрвообразите, предмет на вековни догматически уточнения, касае също и вариращото вьв времето разграничение на икона и картина, епос и агиография. ВъзАаването на благоговейна почит по йерархия на личностите и изображенията им очертава и йеротопията на пренасяне и вьдворяване на мощи по императорския церемониал на тьржествено влизане в грал (освещаване на

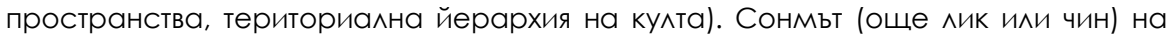
преподобните начело с почитаните още приживе полвижници, основатели на обители уравновесява тенденциите на илеологическо обвързване на цьрквата с Аьржавността. 
софрийски среАновековни градове и области, както и в югозапалните Балкани и близките земи, Аостига Ао времената на латинско културно влияние и исихастки цьрковен отпор² (Zhdrakov, 1995: pр. 295-307, 301), (Zhdrakov, 1993). Тогава се създават средновековните паметници на боянската, търновска и рилска иконографрия на светеца, а по-късно Аругите стари стенописи: ри^ски³, земенски ${ }^{4}$ (Mavrodinova, 1980), погановски, появяват се късносредновековните сеславски, алински, Аобърски, още по-късните Арагалевски, и Аруги варианти. През Възражлането, в Самоков и Суково свети Йоан се рисува в близост Ао композицията „Покров Богородичен" и сякаш става част от нея. СреА множеството забележителни самоковски икони се откроява Плевенската в царския реА на красивия иконостас на вкопания стар храм „Свети Никола". Също така и за отлелните образци на Аругите балкански зографски школи, за паметници като албанската, етрополската и странАжанската и много Аруги отАеАни Икони И Иконни композиции из музеи, галерии, частни колекции, храмове и поклоннически репортажи, за изображенията на светеца Ао наши Ани и по света и дори до полюсите, може $\Delta а$ се каже, че като цяло са известни, публикувани и сравнително Аобре проучени, но все още има какво $а$ а се Аопринесе като инорормация, подходи и систематизация.

На Света гора има около Авалесетина, повече или по-малко представителни изображения на светеца в различен иконографоки контекст (Enev, 1997), (Enev, 1994), (Enev, 2005), (Genova, 2002b) в 3ограdo

2 Зарко ЖАраков, Към въпроса за влиянието на Италианския ренесанс в православното изкуство на Балканите през XV век, В: Ренесансьт и Бьлгария, София, Гея Аибрис, ISBN 954-8232-60-X, 1995, Страници: 295-307, 301, (Zhdrakov, 1995: рр. 295-307, 301) очертава тенлецията на класицизиране свързана с тогавашната цьрковна геополитка и пречупена през цивилизационния отговор на исихасткия хуманизъм във византийското изкуство от късния палеологов периоА на ранния XV век, Към която АонякьАе се отнасят старите изображения на светеца, вьпреки колебанията в стиловия им и археологически анализ;

3 Проучените от профессор ^юбен Прашков стенописи в параклиса „Свето Преображение" на Хрельовата кула със запазени житийни сцени и реставрация Аискутирана днес и от Иван Ванев;

4 Аиляна Мавродинова, Земенската цьрква. История, архитектура, живопис, София, Български художник, ISBN 75-Б(092)ІІІ21 9538274512/7240-24-80, 1980, (Mavrodinova, 1980); стильт се приема за архаичен. 
И в Хилендар и в посветения му там паракАис, вкАючително житийни сцени, Хилендарската икона в критски стил и нови стенописи и икони. Най-логично за българския манастир там е изобразяването му в притворите межАу свети Козма Зографоски и свети Атанасий Атонски, също и със срьбските преподобни и благоверни светии, с ктиторите и т. н. Интересни елементи допринасящи за образите на светеца са обемните и декорирани нимбове и звездите по синия фон на някои цьркви. Нарел с представителните изображения, запазени са и посхематични и стилизирани, някои от които на външни стени и изсивели от времето.

Емблематични образи на светеца са запазени в Рилския манастир, в параклиса на кулата "Преображение Госполне", в цьрквата „РожАество Богоролично“, в обособените в наоса северни параклис "Свети Никола" и южен "Преп Йоан Рилски", за който се прелполага, че е запазен от стария храм. Отлелни параклиси са посветени на свети апостол и евангелист Йоан Богослов и на Свети свети Сава и Симеон Сръбски, а кръщелният - „РожАество Богородично" е нов. Всички тези паметници, обстойно проучени и реставрирани, както и гробищния храм „ВъвеАение Богородично“ и подалечните сгради и храмове в скитовете и метосите по течението на Рилската река на изток и на запал от манастира, Аават еАна богата картина на свети-Йоановата иконографиия.

^юбимо за поклонниците през вековете е мястото на отшелничеството на светеца с пещерата, извора и камъка, наА средновековния скит на Старата постница 5 (Gergova, 2002), (Genova, $2001)$ с цьрквата „Успение на свети Йоан Рилски“, издигната на гроба на светеца и по-кьсно украсена сьс стенописи подобни на манастирския параклис "Свети Йоан Богослов". Още прели откриването на мощите в края на Х век и пренасянето им в Средец, а после и по време на странстванията им, тук монасите са се отАалечавали за молитва през постите като поклонници, възможно най-

5 Уебсайт: Рилска света обител, [Rila Holy Monastery, https://rilskimanastir.org/bg/postnitci-i-metosi/starata-postnitca/, (Last view: 01.04.2019)]; 
близко Ао своя учител. Новата постница, скит „Свети Аука“ на мястото на успението на племенника на светеца, с храмовете „Свети Апостол и Евангелист Аука" и "Покров Богородичен" също има подобно възпоменателно значение. Най-новата, Теодосиева постница, е посветена на патриарх Евтимий и преподобен Теодосий Търновски. Изписана е през 1956 голина от Шелехов с дарения на зографра и рилски монах Теодосий, но и останала недовьршена, без иконостас, при изселването на братството през 1961 голина6. Гробищният манастирски храм „Въведение Богородично“, цьрквата "Св. Петър и Павел" в метоха Орлица и цьрквата "Успение Богородично" в метоха Пчелино за поклонниците са елин живописен разказ на житието на светеца и историята на неговия вековен култ. Богатата митература за тези свети места, образите от тях и Аокументите съживяващи интересните обичаи на еАновремешното поклонничество са незаменим извор, коректив и неизчерпаем инорормационен ресурс за съвременните практики.

Ри^ският манастир като Ауховно среАище свьрзва средновековните, възрожленските и съвременните традиции на Ауховен живот и отразяващите го цьрковни изкуства. Развитието на цьрковната графрика и тиражирането на иконни щампи представящи житието на светеца, успението, мощите и чудотворната икона7 (Genova, 2002a: pp. 45-74, 65) е важна стьпка в цьрковната проповеА осъществявана оттук чрез рилските Ауховници, покАонници и таксиАиоти в цялата страна. В експозицията и библиотеката на манастира могат $\Delta$ a ce видят и художествените материални измерения на тези процеси и как образа на светеца се мени в разнообразни материали и контексти.

6 Уебсайт: Рилска света обител, [Rila Holy Monastery, https://rilskimanastir.org/bg/postnitci-i-metosi/teodosieva-postnitca/, (Last view: 01.04.2019)]

7 Елена Генова, Молели и пьтища за модернизиране на църковната живопис в българските земи от втората половина на XVIII и XIX век, В: Историческо бълеще, ISSN 1311-0144, №2, 2002, Страници: 45-74, 65, (Genova, 2002a: pp. 45-74, 65); Изображението на пренасянето на мощите в цьрковните щампи е обект на проучване на Аюбомир Трайков в Юбилейната научна конференция по случай 550 голини от връщането на мощите на преполобни Йоан Рилски от Търново в Ри^ския манастир, Ри^ска света обител, 18-19 юни 1919 година; 


\section{1 Основни иконни типажи}

Първите иконични образи на светеца могат $\Delta$ а се търсят във времето на успението му, когато местното почитане на духовен старец е преминало в общоцьрковна канонизация на преполобен. СпореА запазените най-стари иконографоки варианти, Анес се прелполага, че пьрвата му Аопоясна икона, каквато Анес се изписва и открива преА народа в момента на прославлението може да е била от средечки тип, а в последствие с развитието на култа (Bakalova, 2016) се одрормя търновски или рилски тип ${ }^{8}$ (Penkova, 2008). Появата на стенописите в ця^ ръст се свързва с мястото на рак(^)ата с мощите при няколкото пренасяния9 (Hristova, (eds.), 1993) и пьрвите храмове посветени на преполобния Йоан Ри^ски. Житийните икони и стенописи, щампи и произведения на приложното изкуство вероятно са започнали $А$ се появяват столетие по-късно, както е било закономерно във византийското изкуство (Bakalova, 1986). Съвременните пок^онници в търсене на оптималното изображение илюстриращо словесния образ запазен в житията и мругата цьрковна митература се опитват $\Delta а$ реконструират образа на свети Йоан максимално близко Ао найстарите към момента съхранени и Аостигнали $А$ нас иконни изображения. Но оправлано ми е това, ако е общоприет Аруг образ?

СлеА изобилието на пищна възрожАенска иконографоия, послеАвана от акалемичната и стилизираната икона, Анес ни е трулно $\Delta$ с се върнем на сльржания образ на византийската рилска икона от XIV век. В нея светецьт е изобразен статично, масивно, близко Ао стила на Панселинос, без излишно $\Delta$ а се Араматизира, нито мика, нито монашеското облекло символизиращо още и Ауховна раАост и нетленние. Светецьт Аьржи кръста зараво и изправено като орьжие,

8 Бисерка Пенкова, Образьт на свети Йоан Рилски в Боянската цьрква, В: Старобьлгарска митература, Том 39-40, №1, 2008, ISSN 2535-0919, 0204-868X, Страници: 163-183, (Penkova, 2008); стенописта е от 1259 година, но някои автори преАполагат, че образът и наАписът на свитъка на светеца е среА няколкото поКьСНи;

9 Пренасянето на мощите на свети Йоан Рилски през 1469 голина в светлината на историческите събития, В: Христова, Боряна (отг. реА.), Българският XV век, Соория, НБКМ, ISBN: 954-523-004-5, 1993, Страници: 85-92, (Hristova, (eds.), 1993); 
свитькьт прибран и нищо не разсейва зрителя. Копие на тази икона, от хисарския зографр Мирослав Анес се пази в РотонАата „Свети Георги“ в София, къАето худоЖникът изписва иконостаса. Интересно е, колко различна по сти^ и близка по функции е популярната народна печатна икона, преА която повечето хора се обрьщат към светеца Синолалната цьрковна картина от средата на миналия век от Михаил Малецки ${ }^{10}$ (Bonov, 2007), в която хуложникьт акцентира на монашеските олежАи с техните символи, на очите и бралата. Някъле в храмовете се появяват и картини на светеца с още по-изразителен поглеА, кьАето светецьт е с открита глава и друго облекло, Аругале бива бос или с бенни Арехи.

\section{2 Свитъците в ръцете на свети Йоан Рилски}

Ауховните послания по свитъците на иконите и стенописите на преподобния светец Йоан Рилски Чудотворец се обогатяват нареА с иконографрията. Ао нас заеАно с иконите като свиАетели на почитта към светеца-покровител са Аостигнали множество старобългарски, новобългарски, църковнославянски и съвременни текстове, чрез които преподобният отец не спира да отправя своите молитви и призиви свисше. Изписани калиграфрски, тези откъси от свещена митература все повече се възприемат, и от художниците, и от вярващите, почти като декорация към иконата. Визуално познатите Ауми възАействат културно и цьрковно, но не винаги се забелязват и четат като жива проповел и

10 Йонко Бонов, Художникът Михаил Малецки, София, Екопрогрес, ISBN 978-9549447-28-6, 2007, (Bonov, 2007). ЕАна от Авете икони на Малецки спечелили синолалния конкурс за образ на преполобния по случай юбилея през 1946 е отпечатана в голям тираж, разпространена из цялата страна и представяща светеца с покрита глава, в масленозелен колорит, патерица в Аясната рька и Свитьк Аолу в Аявата с Аумите „ГоспоАи, возАюбих...". Вероятно по същия повоА е нарисувана от Ростовцев иконата на светеца в притвора на Руската цьрква, къАето той е представен тържествено и Аинамично, в тъмни Арехи на наситен син фон, с прозрачен ореол и с открита глава, същия налпис на свитька, но изцяло изписан и обьрната към вярващите Аесница, полобно на пощенската марка на Гюлженов и цветната щампа на Харалампи Тачев. Отлелно още през 1938 година образът на светеца от Малецки е разпространен в печатен каталог по целия свят, заедно с останалите спечелили межАународен конкурс негови акалемични икони на основните и български светийски персонажи, повлияни от образци на руски хромолитографии. 
благословия към православните християни от всички времена. Някога мъдрото слово на светеца е било насочено към неговите последователи в монашеския живот. НевеАнъж в трудни и размирни времена това е било малкото, което е можело $\Delta а$ Аостигне $\Delta о$ хората ^ишени от цьрковен живот. Например, Анес актуално за съвременните

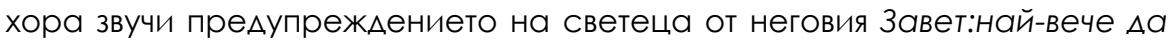
се пазим от змията на сребролюбието, защото то е корен на всяко з^о, спореА Апостола, който го нарича второ илолослужение. Затова заслужава интерес възможността за вникване в значението на български ${ }^{11}$ на текстовете от свитька на светеца, които поклонниците могат да открият на пръв поглеА в отАелните стари и съвременни изображения като небесно светоотеческо послание (Приложение 1).

Сьпоставката на множеството цьрковни текстове, изображения и символи свързани със сакралната репрезентация на свети Йоан Рилски Чулотворец и нейните проучвания разкрива в Аетайл някои културни явления в конкретния цьрковно-исторически и актуален поклоннически контекст на възприемане на изкуството, които заслужават по-нататьшно изследване. От перспективата на отговорността за съхранение, представяне и Аигитализация на материалното и живото културно наслелство преАстои Аа бъ $е$ направено още много за $\Delta$ а се подсигури една оптимална основа за полобряване на съществуващите практики с цел те $а$ а се интегрират устойчиво в приоритетните области на социалния живот.

\section{Бележка. Приложенията към този текст може Аа виАите в края на сборника.}

11 За целите на това проучване не се привеждат точните текстове и техните преволи, тъй като резултатите от палеографрските изслеАвания варират при различните паметници, но тук се търси проследяването на възможностите за непосредствено възприемане и разговорна интерпретация. 


\section{Аитература / References}

Arizanova, Silviya, (2014). Apparel in the World of Bulgarians in 12th-14th Centuries (in Bulgarian), In: Kostova, Rosina (ed.), Medieval People and their World, Publisher: Faber, Veliko Tarnovo, Bulgaria, ISBN ISBN: 978-619-00-0108-9, 2014, Pages: 633-644 // [Аризанова, Силвия, Облеклото в света на българите през XII-XIV век. - В: Костова, Росина (сьстав.), Средновековният човек и неговият свят, Велико Търново, Фабер, ISBN 978-619-00-0108-9, 2014, Страници: 633644];

Bakalova, Elka, (2016). The Cult to Relics and Miraculous Icons: Traditions and Contemporaneity (in Bulgarian), Publisher: IEFSEM-BAS, Sofia, Bulgaria, ISBN 978954-322-836-2, 2016 // [Бакалова, Е^ка, Култьт Към реликвите и чуАотворните икони. Традиции и съвременност, Софрия, ИЕФЕМ-БАН, ISBN 978-954-322836-2, 2016];

Bakalova, Elka, (1986). To the Interpretation of Earliest Hagiographical Cycle about Saint John of Rilla in Visual Art, In: Cyrillo-Methodian Studies, Volume 3, 1968, ISSN 0205-2253, Pages: 146-153 // [Кьм интерпретацията на най-ранния житиен цикъ^ за Иван Рилски в изобразителното изкуство, В: КирилоМетодиевски студии, Том III, 1986, ISSN 0205-2253, Страници: 146-153];

Bonov, Yonko, (2007). The Artsit Michael Maletsky (in Bulgarian), Publisher: Ekoprogress, Sofia, Bulgaria, ISBN 978-954-9447-28-6, 2007 // [Бонов, Йонко, Художникът Михаил Малецки, Софиия, Екопрогрес, ISBN 978-954-9447-28-6, 2007];

Enev, Michail, (1997). Rilla Monastery (in Bulgarian), Publisher: Balkan, Sofia, Bulgaria, ISBN: 9549517039, 1997 // [Енев, Михаи^, Ри^ският манастир, Соория, Балкан, ISBN: 9549517039, 1997];

Enev, Michail, (1994). Athos - Zographou Monastery (in Bulgarian), Publisher: Kybela, Sofia, Bulgaria, ISBN 954-8408-01-5, 1994 // [Атон - манастирьт Зограф, Софиия, Кибела, ISBN 954-8408-01-5, 1994];

Enev, Michail, (2005). The mural images of St. John of Rila in the monasteries and chapels of Holy Mount - Athos (in Bulgarian), In: Seminarist Newspaper, № 2, April 2005, № 3, May 2005 // [3а Стенописните изображения на свети Йоан Ри^ски в манастирите и параклисите на Света Гора - Атон, Вестник Семинарист, № 2, априх 2005, № 3, май 2005];

Genova, Elena, (2001). Church at the Tomb of Saint John of Rilla. Murals, and Painters (in Bulgarian), In: Slavonic Saints in the History of Christian Church, Annual of Sofia University: Centre of Slavic-Byzantine Studies, Volume 91 (10), 2001, ISSN 131 1-784X, Pages: 133-146, 319-329 // [Цьрквата при гроба на 
свети Йоан Ри^ски. Стенописи и Зографии, В: САавянските светци в историята на християнската цьрква. Голишник на Софийския университет: Центьр за славяно-византийски проучвания, Том 91 (10), 2001, ISSN 1311-784X, Страници: 133-146, 319-329];

Genova, Elena, (2002a). Models and Ways of Modernisation of Church Painting in Bulgarian Lands from Second Half of 18th and from 19th Centuries (in Bulgarian), In: Historical Future, ISSN 131 1-0144, No 2, 2002, Pages: 45-74 // [Генова, Елена, Молели и пьтища за модернизиране на цьрковната живопис в българските земи от втората половина на XVIII и XIX век, В: Историческо бъдеще, ISSN 131 1-0144, №2, 2002, Страници: 45-74];

Genova, Elena, (2002b). Parallels between Monuments of Monumental Mural Painting in Rilla Monastery and Zographou Monastery on Athos from the Second Half of 18th Century (in Bulgarian), In: Tepavicharova, Paulina (ed.), Agiorite Cloister Zographou, Volume II, Sofia, University Press, 1996, Pages: 309325 // [Паралели межлу паметници на монументалната живопис в Ри^ския манастир и манастира Зографр на Атон от втората половина на XVIII век, B: Тепавичарова, Паулина (съст.), Светогорска обител Зографр, Том II, Соория, Университетско изАателство, 1996, Страници: 309-325];

Gergova, Ivanka, (2002). Grave of Saint John of Rilla (in Bulgarian), In: Пıтún: Studies in Honour of Professor Ivan Marazov, Publisher: Anubis, Sofia, Bulgaria, ISBN 9544264310, 2002, Pages: 599-607 // [Иванка Гергова, Гробът на свети Йоан Рилски, В: Гичева, Росица, Косталин Рабалжиев (състав.), Пıти́n: Изследвания в чест на профр. Иван Маразов, Софрия, Анубис, ISBN: 9544264310, 2002, Страници: 599-607];

Goshev, Ivan, (1957-1958). Old-Bulgarian Services for Entering Monasticism: Text, Translation, and Comment (in Bulgarian), In: Annual of Theological Academy, Volume 7(33), 1957/1958, ISSN 0323-9578, Pages: 407-447 // [Гошев, Иван, Старобьлгарски чинопоследования за встьпване в монашество: Текст, прево и и коментар, В: Голишник на Ауховната акалемия, Том 7(33), 1957/1958, ISSN 0323-9578, Страници: 407-447];

Goshev, Ivan, (1932). The Apparel of Old-Bulgarian Monks according to ByzantineBulgarian Sources from 9th-1 1 th Centuries (in Bulgarian), In: Proceedings of National Ethnographic(al) Museum, Volume X-XI, 1932, ISSN C610-8377, Pages: 37-72 // [Облеклото на старобьлгарските монаси спореА византинобългарски извори от IX-XI вв., В: Известия на народния етнограф(иче)ски(я)музей, Том X-XI, 1932, ISSN C610-8377, Страници: 39-72];

Hristova, Boryana, (eds.), (1993). Balgarskiyat XV vek (in Bulgarian). Sofia, Bulgaria, NBKM, ISBN: 954-523-004-5, 1993, рр. 85-92 // [Христова, Боряна (отг. реА.), Българският XV век, Софрия, НБКМ, ISBN: 954-523-004-5, 1993, Страници: 8592]; 
Koev, Evgeny; Piperkov, Paskal, (2017). On the Route of Transfer of the Relics of St. John of Rila from Sredetz to Tarnovgrad in 1195. Chronology of the Pilgrimage March "St. John of Rila" 2016 (in Bulgarian), Science series Cultural and Historical Heritage: Preservation, Presentation, Digitalization (P. Petkov \& G. Bogdanova, Eds.), volume 3, issue 1, pp. 70-100, ISSN: 2367-8038, http://www.math.bas.bg/vt/kin/files/papers/3_1/06-KIN-3-1-2017.pdf

Manova, Ekaterina, (1962). Kinds of Medieval Apparels according to Murals from 13th-14th Centuries (in Bulgarian), In: Proceedings of National Ethnographic(al) Museum, Volume V, 1962, ISSN C610-8377, Pages: 5-73 // [Манова, Екатерина, Вилове среАновековни облекла спореА стенописите от XIII - XIV вв. в Югозапална България, В: Известия на Етнографския институт и музей, Том V, 1962, ISSN C610-8377, Страници: 5-73];

Manova, Ekaterina, (1961). Garments and Materials in the Painting of Zemen Church (in Bulgarian), In: Archaeology, No2, 1961, ISSN 0324-1203, Pages: 1-7 // [Облекла и тъкани в живописта на Земенската цьрква, В: Археология, №2, 1961, ISSN 0324-1203, Страници: 1-7);

Matakieva-Lilkova, Theophana, (1981). Bulgarian National Saint in Medieval Visual Art 13th-15th centuries (in Bulgarian), In: Giyzelev, Vassil, (ed.), History, Art, and Culture of Medieval Bulgaria, Publisher: Narodna Prosveta, Sofia, Bulgaria, 1981; Pages: 196-210 // [Матакиева-Аилкова, Теофана, Българският национален светец в среАновековното изобразително изкуство XIII-XV вв., В: Гюзелев, Васи^ (сьстав.), История, изкуство и култура на средновековна България, София, Народна просвета, 1981, Страници: 196-210];

Matakieva-Lilkova, Theophana, (1980). Ivan Rilsky and Tarnovo Cultural Traditions (in Bulgarian), In: Vekove, No 1, 1980, ISSN 0324-0967, Pages 5-15 // [Иван Ри^ски и търновските културни традиции, В: Векове, №1, 1980, ISSN 0324-0967, Страници: 5-15];

Matakieva-Lilkova, Theophana, (1978). Image of Saint John of Rilla in Bulgarian Visual Art (in Bulgarian), In: Proceedings of Church-Historical Institute and Archive and Church-Historical and Archaeological Museum, Volume 1, 1978, Pages: 87-1 16 (Образьт на свети Иван Рилски в българското изобразително изкуство, В: Известия на цьрковноисторическия институт и архив и на Църковноисторическия и археологически музей, Том 1, 1978, Страници: 87116);

Mavrodinova, Lilyana, (1980). Zemen Church: History, Architecture, Painting (in Bulgarian), Publisher: Balgarski hudozhnik, Sofia, Bulgaria, ISBN 75-5 (092) III 21 9538274512/7240-24-80, 1980 // [Мавродинова, Аиляна, Земенската цьрква. История, архитектура, живопис, Софрия, Български хуАожник, ISBN 75Б(092)|II21 9538274512/7240-24-80, 1980]; 
Penkova, Bisserka, (2008). The Image of Saint John of Rilla in Boyana Church, In: Old Bulgarian Literature, Volume 39-40, No 1, 2008, ISSN 2535-0919, 0204-868X, Pages: 163-183. (Пенкова, Бисерка, Образът на свети Йоан Рилски в Боянската цьрква, В: Старобьлгарска литература, Том 39-40, №1, 2008 , ISSN 2535-0919, 0204-868X, Страници: 163-183);

Piperkov, Paskal, (2016). Studies of Places, Related to St. John of Rila. Chronology of the Pilgrimage March "St. John of Rila" 2015 (in Bulgarian), Science series Cultural and Historical Heritage: Preservation, Presentation, Digitalization (P. Petkov \& G. Bogdanova, Eds.), volume 2, issue 1, pp. 117-126, ISSN: 2367-8038, http://www.math.bas.bg/vt/kin/files/papers/2_1/13-KIN-2-1-2016.pdf

Pulos, Panteleymonos, Archimandrite, (1992). Saint John of Rilla: Eternal Cellestial Patron of Bulgarian People, Publisher: University Press, Sofia, Bulgaria, 1992 // [Пу^Ос, Пантелеймон, Архимандрит, Свети Иван Рилски: вечен небесен покровител на българския народ, София, Университетско изАателство, 1992];

Zhdrakov, Zarko, (1995). On the Issue of the Influence of Italian Renaissance on Eastern Christian Orthodox Art on the Balkans in 15th Century, In: Renaissance and Bulgaria, Publisher: Geya Libris, Sofia, Bulgaria ISBN 954-8232-60-X, 1995, Pages: 295-307 // [ЖАраков, Зарко, Кьм въпроса за влиянието на Италианския ренесанс в православното изкуство на Балканите през XV век, В: Ренесансът и България, Софрия, Гея Аибрис, ISBN 954-8232-60-X, 1995, Страници: 295-307];

Zhdrakov, Zarko, (1993). Translation of Relics of Saint John of Rilla in the Light of Historical Events, In: Christova, Boryana (ed.), Bulgarian 15th Century, Sofia, Bulgarian National Library, ISBN: 954-523-004-5, 1993, Pages: 85-92 // [Пренасянето на мощите на свети Йоан Рилски през 1496 голина в светлината на историческите събития, В: Христова, Боряна (отг. реА.), Българският XV век, Софияя, НБКМ, ISBN: 954-523-004-5, 1993, Страници: 85-92);

Zhivov, Viktor, (2002). Sanctity: Short dictionary of Hagiographic Terms, Publisher: Slavica, Sofia, Bulgaria, ISBN 954-8520-15-X, 2002 (Живов, Виктор, Светостта: кратьк речник на агиографските термини, Софрия, Славика, ISBN 954-852015-X, 2002); 
КУАТУРНО-ИСТОРИЧЕСКО НАСАЕАСТВО: ОПАЗВАНЕ, ПРЕАСТАВЯНЕ, АИГИТААИЗАЦИЯ

\section{CULTURAL AND HISTORICAL HERITAGE: PRESERVATION, PRESENTATION, DIGITALIZATION}

Научна пореАица: брой 1(6), гоАина V (2019)

Science series: volume 1(6), year V (2019)

\section{ISSN: 2367-8038}

\section{Релактори \\ Петко Ст. Петков \\ Галина БогАанова \\ Институт по математика и информатика БАН, Бъмгария}

Материалите в сборника са обект на авторско право. Разрешава се безвъзмезАното ползване на техни електронни/ хартиени копия само

за лична употреба или с цеА обучение, при писмено указание за Аипса на търговски намерения и пь^но цитиране на текста от тази

страница.

За копиране пол Аруга орорма, препубликуване или публикуване на сървъри се изисква писмено разрешение и/или зап^ащане.

() Авторски колектив, 2019

Технически реАактори: Николай Ноев, гА. ас. А-р Калина Сотирова-Вълкова, ас. А-р

\author{
Editors \\ Petko St. Petkov \\ Galina Bogdanova \\ Institute of Mathematics and \\ Informatics \\ BAS, Bulgaria
}

This work is subject to copyright. Open and free use of digital/ hard copies of publications is granted only for personal or educational use, while there are written statement for not-commercial intention and full citation of the text of the current page.

For any other reproducing types, re-publishing, photocopying, recording, orany other storage retrieval system/server is required written permission and/or fee.

(C) Authors` Group, 2019

Technical editors:

Nikolay Noev, Assist. Prof. PhD Kalina Sotirova-Valkova, Assist. Prof. $\mathrm{PhD}$ 